\title{
ІНТЕРТЕКСТУАЛЬНА МОДАЛЬНІСТЬ МОЛОДОЇ УКРАЇНСЬКОЇ ПОЕЗЇ̈ ПОЧАТКУ ХХІ СТОЛІТТЯ
}

\author{
ОКСАНА ПУХОНСЬКА
}

Київський університет імені Бориса Грінченка, Київ - Україна

\author{
INTERTEKSTUALNA MODALNOŚĆ W MLODEJ POEZJI UKRAIŃSKIEJ \\ POCZĄTKU XXI STULECIA \\ OKSANA PUCHOŃSKA \\ Uniwersytet Kijowski im. Borysa Grinczenki, Kijów - Ukraina
}

STRESZCZENIE. W artykule została poddana analizie intertekstualność ukraińskiej poezji najmłodszej generacji, której literacka kariera przypada na początek XXI wieku. Kluczowe aspekty intertekstualności zostały rozpatrzone w najbardziej typowych dla współczesnej poezji środkach, takich jak cytaty, aluzje, reminiscencje oraz na przykładzie analizy motywów domu, wędrówki, poczucia zagubienia itp.

\section{INTERTEXTUAL MODALITY OF YOUNG UKRAINIAN POETRY OF THE BEGINNING OF THE $21^{\text {ST }}$ CENTURY}

\author{
OKSANA PUKHONSKA \\ Borys Grinchenko Kyiv University, Kyiv - Ukraine
}

ABSTRACT. In this article the author examines intertextual peculiarities in the poetry of young Ukrainian writers, whose works were created at the beginning of the $21^{\text {st }}$ century. The main aspects of intertextuality investigated through the prism of the most typical forms of this phenomenon (quotation, allusion, reminiscence) on the basis of selected motives.

$\mathrm{Y}$

країнська культура сьогодні зазнає впливу глобальних інформаційних процесів, що сприяють руйнуванню культурних кордонів, стираючи певним чином національні та етнічні особливості і витворюючи єдиний культурний простір із домінантною претензією на масовість. Окрім епохальних зовнішніх змін, відбуваються ще й істотні внутрішні, як-от формування неколоніальної свідомості в системі порадянського часопростору ${ }^{1}$. Постколоніальна адаптація українського суспільства, розгалуження літературних тенденцій на питомо національні і новаторські - цілком прийнятні означники для процесу становлення нації, інтеграції іiї у ширший культурний простір через художню творчість зокрема ${ }^{2}$. У цьому випадку важливими $є$ саме інтертексту-

${ }^{1}$ Е. Т о м п с о н, Трубадури імперії. Російська література $і$ колоніалізм, перекл. 3 англ. М. Корчинської, Київ 2008, с. 112.

2 Я.О. П о л і щ у к, Література як геокультурий проект, Київ 2008, с. 204. 
альні коди, які дають змогу досліджувати взаємозв'язки нової вітчизняної літератури у вже існуючих літературних дискурсах.

В основі цієї студії - поезія генерації міленіум. Таке визначення дослідники (О. Мальцева, Я. Поліщук, Р. Харчук) пропонують для авторів, що прийшли в літературу на межі тисячоліть.

У вірші кінця 80-х років минулого століття характерним був ліричний персонаж, домінантою світосприймання якого слугувала іронія. Його постава не передбачала жодних морально-етичних настанов, сповідування естетичних цінностей. Життя і світ в умовах краху імперських порядків сприймалися не інакше як гра, в якій не важлива перемога, а лише невідворотна участь ${ }^{3}$. У дев'яності роки вітчизняне мистецтво різко вивільнилось од політичного пресу - аж до цілковитої незалежності від будь-яких суспільних рефлексій, до руйнації книжкового ринку й видалення професії письменника на глибокі соціальні маргінеси ${ }^{4}$. Уже в середині 1990 -х років ліричний герой постає перед проблемою самоідентифікації у соціумі, який перебуває у стані постколоніального одужання.

Початок XXI сторіччя став черговим переломом культурного формування українського суспільства у сфері державотворення, а також інтеграції у міжкультурний простір. В таких умовах народжується молода поезія, де генерація міленіуму втілює власні художні пошуки. Це формує сприятливі умови для урізноманітнення ії̈ стилів, жанрів, проблематики. При цьому ключовою проблемою залишається вписування багатого культурного досвіду (як українського, так і світового) в індивідуальне письмо кожного з молодих авторів. Цей аспект представлений інтертекстуальним пластом. Літературну епоху сьогодні творять нові, часом не зовсім відомі імена, такі як Олег Короташ, Ольга Ляснюк, Олеся Мудрак, Богдан-Олег Горобчук, Тетяна Бондар, Юхим Дишкант, Григорій Семенчук, Мар'яна Лелик та інші.

Проблема інтертекстуальної модальності цілком актуально вкладається у річище сучасного поетичного тексту постмодерного характеру. Виразною ознакою останнього $є$ типове загравання з інтелектуально підкованим читачем через залучення до твору вже наявних у літературі текстових кодів.

Варто зазначити, що до постструктуралізму літературний текст розглядався як автономний мистецький факт, котрий існує сам у собі. Ті дослідники, що йшли слідом за Жаком Дерида, Роланом Бартом та іншими теоретиками і філософами постструктуралізму, поставили під сумнів таку автономію. Більше того, було доведено, що текст $є$ вузлом у значно ширшій мережі суспільних, історичних, культурних та художніх практик Це не тільки змінило сприйняття, а й вплинуло на той спосіб, у який він мав читатися. Таким чином, розрив

${ }^{3}$ I.М. А н д р у с я к, Латання німбів: літературно-критичні статті 2002-2007 років, Івано-Франківськ 2008, с. 67.

${ }^{4} \mathrm{M}$. К і я н о в с ь к а, Знаки поетичних поколінь у найновімій украӥнській поезї̈, [в:] „Українська літературна газета” 2011, № 18, с. 4-5. 
автономії тексту започаткував його інтертекстуальне прочитання 5 . Текст, за Р. Бартом, - це не усталений знак, а умови його породження, живильне середовище, у яке занурений твір. Текст, таким чином, переходить в інтертекст, а твір - ефект тексту, видимий результат текстової роботи, дія якого відбувається на „другій сцені”, шлейф, що тягнеться за текстом ${ }^{6}$. Тут маємо справу 3 численними інтерпретаціями, яких набуває твір у процесі свого існування через прочитування.

За теорією Ю. Крістевої, кожен текст вибудований з мозаїки цитат, він $\epsilon$ засвоєнням і переінакшенням іншого тексту ${ }^{7}$. Міхал Гловінський вважає, що Ю. Крістева веде мову передусім про твердження, за яким не можна аналізувати структуру, якщо не позиціонувати ії в той чи інший спосіб щодо інших текстів ${ }^{8}$. За вченим, хоча інтертекстуальність не є жанровою категорією, у певних випадках - це явище або майже обов'язкове, або досить часте'. У випадку вірша інтертекстуальність імплікується самою позицією наратора, який може вільно переходити від мотиву до мотиву й - передусім - від стилю до стилю.

Поетичний текст, як відомо, розрахований на багатозначне прочитання. За Ю. Лотманом, сприйняття поетичного тексту - явище специфічне. Поезія „живе” у полі перетину багатьох семантичних систем і багатьох „мов”" У поезії завжди відбувається полілог різноманітних систем, зіткнення різних способів пояснення і систематизації різних картин світу. Вірш демонстративно вибудовується на літературних асоціаціях. I хоча в ньому може не бути прямих цитат, одначе він відсилає читача до конкретного культурно-побутового та літературного середовища, поза контекстом якого часто не може бути зрозумілим ${ }^{11}$. Інтертекстуальність у ліриці відчитуємо через образність, домінантні мотиви, проблематику. Усе це невід'ємні складові не лише поезії як літературного роду, а й соціокультурних процесів конкретного часу, що знаходять себе у літературі. У цьому контексті звернемо увагу на форми інтертекстуальності та провідні мотиви, що забезпечують міжтекстову комунікацію в поезії молодих українських авторів. Найбільш використовуваними формами є u̧итати, алюзї̈, ремінісиенщіï.

${ }^{5}$ Ч. В і н к в і с т, В. Т е й л о р (ред.), Енциклопедія постмодернізму, перекл. $з$ англ. В. Шовкуна, Київ 2003, с. 171.

${ }^{6}$ Р. Б а р т, Избранные работы. Семиотика. Поэтика, перев. с франц. Г. Косикова, Москва 1989, с. 40.

7 3. М і т о с е к, Теорії літературних досліджень, перекл. 3 польск. В. Гуменюка, Сімферополь 2005, с. 341.

${ }^{8}$ М. Г л о в і н с ь к и й, Інтертекстуальність, перекл. $з$ польск. С. Яковенка, [в:] Б. Б а к у л а (упоряд.), В. М о р е н е ц ь (ред.), Теорія літератури в Польщі. Антологія текстів. Друга половина XX-початок XXI ст., Київ 2008, с. 287.

${ }^{9}$ Там само, с. 293.

${ }^{10}$ Ю.М. Л о т м а н, Анализ поэтического текста, Ленниград 1972, с. 109.

${ }^{11}$ Там само, с. 113-115. 
Ролан Барт розглядав цитату як сукупність можливих дискурсів, з яких складається культура і в атмосферу яких, незалежно від своєї волі, занурений кожен автор ${ }^{12}$. За К. Козицькою, цитата, взята із якого-небудь тексту-попередника (претексту, тексту-джерела), входить у заново створений авторський текст, у якому має подвійне значення. 3 одного боку, вона $€$ органічною частиною нової структури, а з іншого, - генетично чужорідний елемент, що зберігає у собі пам'ять про текст-джерело ${ }^{13}$. Найтиповішими формами у поетичній майстерні покоління міленіуму є марковані циитати, циитати-імена, та епіграфи ${ }^{14}$.

Під час маркування цитат звертаємо на увагу друкарські засоби: лапки, курсив. Рідко трапляються прямі покликання на той чи інший твір або автора. У випадку цитати-імені маємо справу з іменами авторів, літературних героїв, назвами творів, в окремих випадках - із іменами відомих особистостей, назвами творів інших видів мистецтва тощо. Ім'я є своєрідним знаком, що провокує асоціативні уявлення. Якщо слідувати бартівському розумінню поняття тексту, то автор також є текстом, наділеним певним змістом, важливим у сфері літератури.

Актуальним для українських поетів став мотив смерті у Парижі, який започаткував Сесар Вальєхо. У вітчизняній ліриці його розвинули Наталка Білоцерківець та Юрій Андрухович. У поезії Олени Максименко цей мотив входить у авторський текст через цитату, взяту в лапки без конкретного посилання:

Перша ночі по Цельсію. Сніг в босоніжках не тане.
Понад Римом дощі із, напевно, святої води.
Хтось у каву додасть трохи лондонських свіжих туманів.
„Ми помрем не в Парижі”, та все ж таки будем на „ти”.15.

Авторка цитує Н. Білоцерківець, надаючи своєму творові дещо іншого семантичного звучання, хоча фоностилістичні особливості близькі до первинного тексту. Б.-О. Горобчук використовує у власній поезії цитату із В. Сосюри: вказавши на автора, надає їй іншого значення у змістовому континуумі свого твору:

...що може з тобою статися взагалі

це стосується також іншого героя - Сосюри - це він написав

Я не знаю, хто кого морочить

\footnotetext{
${ }^{12}$ Р. Б а р т, $S / Z$, перев. с франц. Г. Косикова, Москва 2001, с. 18.

${ }^{13}$ Е.А. К о $з$ и ц к а я, Цитатное слово в газетном заголовке и рекламном тексте: пособие по спеикурсу, Тверь 2001, с. 7.

${ }^{14}$ Е.А. К о $з$ и ц к а я, Смыслообразующая функиия и̧итаты в поэтическом тексте: пособие по спеикурсу, Тверь 1999, с. 42.

${ }^{15}$ О. М а к с и м е н к о, Перша ночі по Цельсію..., [в:] Літпошта: збірка молодої поезії, $і$ не тільки..., М. Шунь, І. Павлюк, О. Жупанський (упоряд.), Київ 2009, с. 75.
} 
але я б нагана знову взяв і стріляв би в кожні жирні очі в кожну шляпку і манто стріляв ...нестерпно важко пробачити Сосюрі те, чого він не робив вистачає того, що він зробив для повного й остаточного безсмертя ${ }^{16}$.

Поет переосмислює репресивну історію першої половини XX століття на тлі творчості окремих авторів (у нашому випадку Сосюри), аби проілюструвати значення і бачення іiі з точки зору психології суспільства та зокрема людини століття XXI-го. Окрім маркованої цитати, Б.-О. Горобчук вдається безпосередньо до критичної рефлексії Сосюри в поетичній площині свого твору, привносячи контекст іншого автора, його доби і творчості. Це провокує своєрідну гру розгадування кодів, закладених на рівні історії літератури загалом.

Важливими і репрезентабельними формами інтертекстуальності, що присутні у поезії, $є$ алюзія та ремінісценція. Алюзія - зазвичай прихований натяк на будь-який твір літератури чи мистецтва, щодо особи чи події17. Це навмисне використання поетом у своєму тексті впізнаваних елементів із інших джерел, попередніх чи сучасних, текстуальних чи позатекстуальних. Інтертекстуальна функція поняття полягає у здатності алюзії викликати асоціативні відчуття раніше створених контекстів. За М. Бахтіним, навіть легка алюзія на чуже висловлювання створює ситуацію діалогу ${ }^{18}$. Функція алюзії - відсилання до іншого тексту - як правило, доповнюється встановленням тотожності на сюжетно-образному рівні.

Апокаліптичне сприйняття світу і людини в ньому стає домінантою творчості молодих поетів. Вони часто апелюють до відомих творів, близьких за проблематикою. До прикладу, у вірші Олега Коцарева Готель „Мармуровий жовтень" маємо алюзію Дантового Пекла. Воно стає своєрідним прообразом майбутнього:

...бачу як з верхніх і нижніх вікон випадають люди, що отримали Вичерпні дані про обсяги глобальної кризи Не тому що злякались

А тому що втомились уявивши скільки кіл Скільки бронзових сфер підземель діамантових I розв'язок водяних їм доведеться пройти наново ${ }^{19}$.

У цьому дискурсі також варто звернути увагу на вірш О. Ляснюк:

привезли у подарунок кедрового горіха із Сибіру а він має запах очей тих кого знищили мама казала щоб я посадила зерня

${ }^{16}$ Б.-О. Г о р о б ч у к, Місто в моєму тілі: поезї, Київ 2007, с. 55.

${ }^{17}$ J.A. C u d d o n, A dictionary of literary terms, London 1979, p. 31.

${ }^{18}$ М.М. Б а х т и н, Эстетика словесного творчества, Москва 1979, с. 275.

${ }^{19}$ О. К о ц а р е в, Готель „Мармуровий жовтень”, [в:] Літпошта..., зазнач. джерело, c. 10 


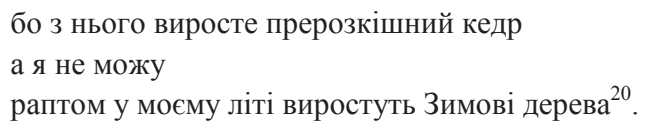

Образ Зимових дерев запозичений із назви збірки поета-дисидента Василя Стуса. Авторка зберігає велику літеру, як ознаку власної назви. Маємо справу саме $з$ алюзією, суть якої полягає в підкресленні проблеми, що іiі поетка порушує у перших рядках твору, де „кедровий горіх із Сибіру має запах очей тих, кого знищили". Вже цю фразу можна вважати алюзією на масові репресії української інтелігенції впродовж тривалого панування радянської імперії. Алюзія в цьому випадку, як форма інтертекстуальності, - не частковий, другорядний елемент твору, а вказівка на суттєву грань авторського задуму, принципово важливий прийом художнього смислоформування і одночасно звернення до авторитетної, на думку поетки, літературної традиції.

Свідомий поетичний прийом ремінісиенції розрахований на пам'ять читача. Запозичені елементи, що натякають на творчість іншого автора, викликають у реципієнта складні асоціації, що збагачують сприйняття твору ${ }^{21}$. Репрезентабельною формою інтертекстуального прочитання є жанрова ремінісценція. Актуальні в цьому випадку твори Павла Коробчука Бог як гіперпосилання, Безпровідний рай, Богдани Матіяш Розмови з Богом, Софії Сітало Твої висновки щось недобре з тобою зробили, Артема Захарченка 3 нотаток Київського природничого товариства. Уваги заслуговує триптих Сергія Осоки Три чорні молитви, у якому форма верлібра містить у собі жанрові ознаки молитви:

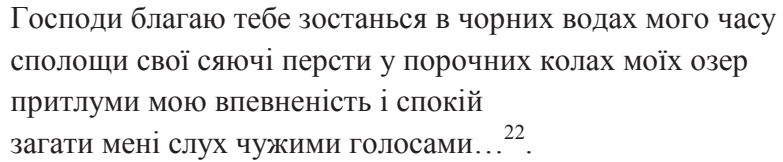

Автор використовує речитативну форму молитви і специфічну лексику типу „перста”, „порочні” тощо. Такі засоби зумовлюють двопланове прочитання твору: як вірша та як олітературеної форми молитви. К. Козицька вважає, що ремінісценція збагачує авторський текст своїми прямими, не трансформованими значеннями. Ці значення традиційні. Завдання ремінісценції - поширити таку якість традиційності на весь заново створюваний твір, упевнити, що він містить уже відоме, підтверджує уже сказане ${ }^{23}$.

Категорія мотиву, поруч із категорією тексту, стає особливо значущою для інтертекстуального аналізу, оскільки саме на це поняття опираються уяв-

${ }^{20}$ О. Л я с н ю к, Привезли у подарунок..., [в:] Дві тони: антологія поезї двотисячників, Б.-О. Г о р о б ч у к, О. Р о м а н е н к о (упоряд.), Київ 2007, с. 162.

${ }^{21}$ Краткая литературная эничилопедия: в 9 т., т. 4, Москва 1967, с. 254.

${ }^{22}$ С. О с о к а, Три чорні молитви, [в:] Дві тони..., зазнач. джерело, с. 195.

${ }^{23}$ Е.А. К о з и ц к а я, Смыслообразующая функииия цุитатыл..., зазнач. праця, с. 58. 
лення про смислові зв'язки всередині тексту і між текстами ${ }^{24}$. У досліджуваній нами сфері інертекстуальної модальності найактуальнішими є ті мотиви, коріння яких сягає глибокої давнини і має багате висвітлення на різних етапах словесної творчості. У цьому випадку звернемо увагу на міфологічні та християнські мотиви, а також біблійні сюжети у контексті міфологічного світогляду, які останнім часом набувають актуальності у різноманітних інтерпретаціях.

Конкретну увагу звернемо на класичну грецьку та слов'янську міфології. Поетичне осягнення потойбічного світу через міфологічні уявлення досить часто репрезентоване в образах загробного царства Аїда, шляху переправи до нього. Така міфологетика - лейтмотивна у творах молодих поетів як декаданс покоління, його шлях у невідомість. У Гітарній крові Юхима Дишканта зустрічаємо:

Сивіє час і жде свого Харона.

У серці Стікс. Яка старезна смерть ${ }^{25}$.

Давньогрецький міф про переправлення душ у царство мертвих перевізником Хароном через річку Стікс поет естетизує, олюднює і осучаснює, бо його покоління живе так, „ніби час нам сьогодні вмерти”. Ліричний герой мислить себе у контексті своєї генерації, разом із якою „вливає у пляшку” хай навіть Стікс і не помічає, що „годинник” замовк уже давно. Час зупинився, або його просто не беруть до уваги, живучи кожен день, як востаннє.

Цей мотив відкриває інтертекстуальне поле прочитання як в українській, так і в зарубіжній поезії. До прикладу, у вірші М. Зерова Класики: „...олос

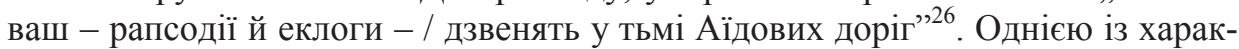
терних ознак творчості українських неокласиків було звернення до античної традиції, відродження іії в новому світлі вітчизняної культури. Це саме помічаємо і в західноєвропейській поезії. Так, Шарль Бодлер у вірші Дон Жуан y пеклі цей мотив розвивав через образ смерті Дон Жуана, з яким ми зустрічаємося саме на березі Стіксу: „Лиш Дон Жуан дійшов до чорних вод Харона / I лепту за провіз дав злому жебраку / Той, наче Антісфен похмурий, водне лоно / Розрізав веслами гладінь од сліз гірку"

Інтертекстуальність аналізованого мотиву має не лише вертикальне вираження (тобто, перегукування на різних часових етапах історії літератури), але й горизонтальне (у поетичних творах одного покоління). Катерина Бабкіна у вірші $O .2$ інтерпретує цей мотив через ремінісценцію: „ти зникаєш ти зовсім стаєш прозорий / хвилі днів дзвенять і гойдають човен" ${ }^{28}$. Авторка уявляє

\footnotetext{
${ }^{24}$ И.В. С и л а н т ь е в, Теория мотива в отечественном литературоведении и фольклористике: очерк историографии, Новосибирск 1999, с. 104.

${ }^{25}$ Ю.Б. Д и ш к а н т, Гітарна кров, Рівне 2007, с. 9.

${ }^{26}$ М. 3 е р о в, Класики, [в:] Золоті рядки української поезї̈: розстріляне відродження, О.В. 3 а в ' я 3 к і н (упоряд.), Донецьк 2008, с. 61.

${ }^{27}$ Ш. Б о д л е р, Поезії, перекл. $з$ франц., Київ 1989, с. 54.

${ }^{28}$ К. Б а б к і н а, О. 2, [в:] Дві тони..., зазнач. джерело, с. 17.
} 
життя як подорож по Стіксу у човні Харона. I кожен день для іiї ліричного персонажа - це крок до зникнення, до „розорення”, тобто до смерті. Тарас Ващук акцентує в цьому мотиві не на закінченні, а на пошукові: „Мій Стікс - ріка безсоння. / Спокійна. Безкінечна. / Вона мені підкаже, / Де віднайти ті ниточки, / Щоб смикати упевнено / Лінивих персонажів" 29.

Слов'янський язичеський образ бога Перуна набуває особливого значення в поетичній творчості багатьох українських авторів. Цей мотив пов'язаний 3 легендою про хрещення Русі, коли статую-ідола Перуна скинули у Дніпро. Анна Багряна у своїй поезії позиціонує цей образ як національний, невіддільний від сутності українства:

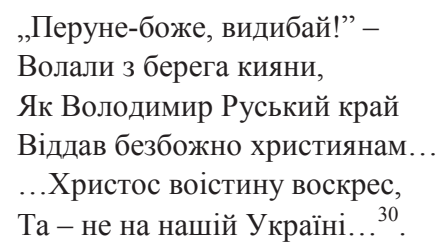

До цього мотиву зверталася також Оксана Лятуринська. У iï віршах мотив Перуна, а саме легенди про потоплення у Дніпрі, стає метафорою сподівання на його близьке воскресіння у „розбурханому” часі: „Ти ще не вмер, ти ще не вмер! / Через розбурханий Дністер / $з$ Дніпра ти видибаєш, Боже!”’1. Поетеса використала інтертекстуальний прийом алюзії, який апелює до легенди про те, як русичі бігли за ідолом у Дніпрі і кричали: „Видибай, боже!”. Цей же мотив залучає Анна Багряна у цитованій поезії.

У проблематиці міфу біблійний мотив належить до таких, що не втрачають актуальності в літературній творчості. Еразм Кузьма розглядає Біблію як джерело міфів європейської культури і літератури. Проте він доходить висновку, що і вона $\epsilon$ „лише свідченням рецепції більш ранніх міфів" ${ }^{32}$. На думку вчених, $є$ кілька основних функцій біблійного символу для новочасної літератури. По-перше, світ Біблії символізує для новочасного поета усталені, традиційні критерії найзагальнішого, філософського порядку. Вони можуть слугувати своєрідним опертям у пошуку сутнісного, у втіленні найзагальніших засад буття й свідомості людини. По-друге, йдеться про засади віри, про пошуки в цій царині - на противагу суспільному та особистісно-духовному само-

${ }^{29}$ Т. В а щ у к, Мій Стікс, [в:] Ірпінські світанки: поезія і проза учасників всеукрайнської наради молодих літераторів 2007 року, Г.С. Г а й, А.І. Г а й (упоряд.), Біла Церква 2008 , c. 49.

${ }^{30}$ А. Б а г р я н а, Між богами $і$ нами, Київ 2005, с. 14.

${ }^{31}$ О. Л я т у р и н с ь к а, Ти ще не вмер, ти ще не вмер..., [в:] Украӥнське слово. Хрестоматія украӥнської літератури та літературної критики XX ст., В. Я р е м е н к о, Є. Ф е д о р е н к о (упоряд.), кн. 2, Київ 1993, с. 391.

32 Е. К у з ь м а, Категорія міфу в літературознавчих дослідженнях, [в:] Теорія літератури в Польщзі..., зазнач. праця, с. 334. 
ствердженню. По-третє, залучення біблійної символіки означає входження у вимір „наскрізного” часу замість тривіального, профанного часу щоденного буття. По-четверте, Біблія уособлює тисячолітню традицію, зокрема й літературну. Використання ії символіки прилучає письменника до загальноєвропейського культурного середовища, що виросло із двох глобального значення традицій - християнської та античної ${ }^{33}$.

Значна кількість питань літературознавства минулого століття, на думку Н. Фрая, закорінена в герменевтичних студіях Біблії ${ }^{34}$. Їхні особливості формувалися в умовах, коли програма „переоиінки иінностей” Ф. Ніцше на початку XX століття спровокувала реорганізацію світогляду, а смілива заява про те, що „Бог помер”, лягла в основу багатьох критичних методів, зокрема літературознавчих. Ми вже неодноразово акцентували увагу на тому, що початок XXI століття знаменується черговим зламом культурної свідомості людства, черговою переоцінкою цінностей, духовних у тому числі. Бог стає „земним”, не сакральним, а близьким до людей чи навіть олюдненим. Такими мотивами характеризується значний пласт молодої поезії.

У Анни Малігон такий мотив закодований графічно у вірші „бачиш, як з чорної скрині...”: „...вуха рудої вівчарки / всотують мокрі звуки березневого потойбіччя / разом із кашлем ГОСПОДАря" 35 , Ірина Шувалова вдається до олюднення цього образу в інтимній ліриці: „Це змога утвердити смерть як наступну сторінку / яку перегорне твій погляд, спрямований в сонце / коли ти ітимеш на небо (ти - бог, а я - жінка)... "36. Софія Сітало у вірші Твої висновки щось недобре з тобою зробили звертається до Бога не лише до того, хто просто поруч, а як до живої, присутньої тут і зараз істоти: „Господи, дай мені спокій! Господи, хвилиночку помовчи!”37, у Павла Коробчука „бог як гіперпосилання "38. Неординарна обробка мотиву у творі Світлани Богдан Царство Земне. Авторка творить „світ навпаки”. На тлі типових проблем свого часу вона із сарказмом роль божественного втілює в образі людини, для якої ці типові проблеми - це лише елементи земного Едему, куди Бог може тільки проситися:

Нині в міліції облава на перекупок у метро.

В контролерів - полювання на зайців у тролейбусах.

${ }^{33}$ Я.О. П о л і щ у к, Символи і метаморфози. Своєрідність християнської символіки в модерній українській поезї̈ перших десятиліть ХХ століття, [в:] „Дивослово” 1997, № 12 , c. 2 .

${ }^{34}$ Н. Ф р а й, Великий код: Біблія і література, Львів 2010, с. 19.

${ }^{35}$ А. М а л і г о н, Бачиш, як з чорної скрині..., [в:] Літпошта..., зазнач. джерело, с. 22.

${ }^{36}$ І. Ш у в а л о в а, Теологія, [в:] Літпошта..., зазнач. джерело, с. 55.

${ }^{37}$ C. С і т а л о, Твої висновки щзось недобре з тобою зробили..., [в:] Літпошта..., зазнач. джерело, с. 209.

${ }^{38}$ П. К о р о б ч у к, Бог як гіперпосилання, [в:] Дві тони..., зазнач. джерело, с. 99. 
Це Царство Земне, куди Господь так мріє потрапити.

Він стоїть під дверима і просить: „Врятуй і збережи мене!”’39.

Важливим мотивом, що знаходить вияв у сучасній вітчизняній поезії, $\epsilon$ міф про сотворення першої жінки Єви із ребра Адама, котрий на сьогодні провокує різні інтерпретації ролі жінки у системі світових релігій загалом і християнства зокрема. Ці інтерпретації знаходять безпосередній вияв у художній словесності. Українська література в цьому процесі не $є$ винятком. Наприклад, у Ольги Ляснюк натрапляємо на віршовану мініатюру, у якій, окрім власне аналізованого біблійного мотиву, на рівні ліричного сюжету немає нічого. Проте смисл значно ширший:

$$
\begin{aligned}
& 13 \text {-те ребро } \\
& \text { у твоєму тілі } \\
& \text { Я } \\
& \text { тобі не коле } ?^{40} \text {. }
\end{aligned}
$$

Формальна структура наведеного твору демонструє віртуозну майстерність цілісної розробки біблійного сюжету у межах фактично однієї фрази. Мотив епічного твору інтерпретовано у романтичному дусі і використано для розгортання психологічної колізії вірша. Поетка переосмислює біблійну легенду з точки зору свідомості сучасного ліричного персонажа, адаптує його до певної ситуації. Розуміння того, чому саме „Я” $є$ „13-м ребром у твоєму тілі”, неможливе без знання першоджерела. У цьому ключі відбувається діалог двох текстів різних часових, культурних і семантичних площин у просторі одного поетичного твору, в результаті чого твориться нове смислове поле традиційного біблійного сюжету.

Два Старозавітні мотиви поєднує у своєму вірші Так притримуй мене за нитку... Катерина Калитко. Авторка бере за основу мотив створення першої людини із глини i, власне, створення жінки з ії ребра. Проте трансформує ці мотиви в усвідомлення того, що людина потроху починає гуманізуватись, перестає бути „Глиною”: „Глина трохи над серцем скресла. / Ти усіх починаєш знову. / Я ще вірю в твої ремесла, / Та ребро - не моя основа...."41. (usunieto kursywe)

Глибоку філософську інтерпретацію біблійного мотиву зради прочитуємо у вірші „калюжа, в яку вступила...” вже згадуваної Ольги Ляснюк. Тут поетеса порушує актуальну проблему, яка випливає із асоціативного ряду:

$$
\begin{aligned}
& \text { а коли починали дитячу лічилку } \\
& \text { жоден не хотів Іудою виявитись } \\
& \text { коли ж усі вивернули кишені } \\
& \text { на столі } 33 \text { срібних лишилося }{ }^{42} \text {. }
\end{aligned}
$$

\footnotetext{
${ }^{39}$ С. Б о г д а н, Царство земне, [в:] Дві тони..., зазнач. джерело, с. 25.

${ }^{40}$ О. Л я с н ю к, 13-те ребро..., [в:] Дві тони..., зазнач. джерело, с. 166.

${ }^{41}$ К. К а л и т к о, Так притримуй мене за нитку, [в:] Дві тони..., зазнач. джерело, с. 81.

${ }^{42}$ О. Л я с н ю к, Калюжа, в яку вступила, [в:] Літпошта..., зазнач. джерело, с. 10.
} 
33 срібних - символічна ознака, ціна зради Іудою Христа. Авторка емоційно посилює смисловий контраст, пов'язуючи глобальні проблеми з темою дитячої наївності.

Молода українська поезія сьогодні відстоює чітку претензійну позицію на чільне місце в літературному дискурсі. Важливим аргументом цієї претензії є інтертекстуальна характеристика поезії, що проявляється через апелювання до художньо-словесних кодів, закладених на попередніх етапах формування творчої спадщини, їх реінтерпретацію у пошуках нових стилів, форм, жанрів. Такий підхід відкриває перспективу подолання національної заангажованості та тенденційності в літературі. У поезії молодої генерації характерно поновлюється процес, що з перервами та затримками тривав упродовж минулого століття. 